\title{
La telepsiquiatría: una revolución de la salud mental en tiempos de pandemia
}

\author{
Telepsychiatry: a mental health revolution in times of pandemic
}

\author{
Nicolás Ayala-Servín (D) 1,2,3
}

1Universidad Nacional de Asunción, Facultad de Ciencias Médicas, Cátedra de Psiquiatría, San Lorenzo, Paraguay.
Universidad Politécnica y Artística del Paraguay, Facultad de Medicina, Asunción, Paraguay
Universidad María Auxiliadora, Facultad de Medicina, Asunción, Paraguay

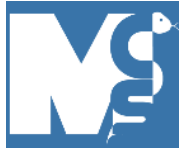

Recibido: 30/04/2021

Revisado: 30/04/2021

Aceptado: 30/04/2021

\section{Autor correspondiente}

Nicolás Ayala Servín Universidad Nacional de Asunción San Lorenzo - Paraguay nicoayala131292@gmail.com

\section{Conflictos de interés}

El autor declara no poseer conflictos de interés.

\section{Fuente de financiación}

\section{El autor no recibió apoyo} financiero para la investigación, autoría y/o publicación de este artículo.

Este artículo es publicado bajo una licencia de Creative Commons Reconocimiento 4.0 Internacional.

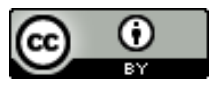

Desde el siglo pasado, la humanidad ha experimentado cambios en diversos ámbitos de la vida y el fácil acceso al conocimiento se facilita gracias al uso de nuevas tecnologías capaces de acortar distancias.

En este contexto, aparecen las Tecnologías de la Información y la Comunicación (TIC) que definimos como las herramientas computacionales e informáticas que procesan, almacenan, sintetizan y representan la información de la más variada forma, facilitando su registro, almacenamiento y difusión. Ejemplos son dispositivos móviles, páginas web, bibliotecas virtuales, plataformas especializadas, entre otros (1).

La salud mental, hoy en día, se enfrenta a nuevos desafíos, como reinventarse y renovar constantemente los métodos para acceder y atender al paciente. En los últimos años, Internet se ha ido convirtiendo en el espacio de investigación en donde se pueden desarrollar procesos de atención médica y promoción de la salud, y la educación científica debe preparar a los profesionales de la salud para analizar y evaluar los nuevos saberes, brindándoles una alfabetización científicotecnológica que les permita ser exitosos.

En varios países se han puesto en práctica estrategias orientadas al uso de plataformas de gestión de contenidos a favor de la salud vía Internet, que buscan innovar, al mismo tiempo que promueven el espíritu investigador y la correcta atención médica con calidad y calidez gracias a las ventajas que tienen las TIC (2).

Sin embargo, el impacto de TIC en Paraguay aún no es muy evidente. Si bien el acceso a Internet va en crecimiento, la instrucción en el manejo de TIC es, en muchos casos, insuficiente; es decir, se dispone de los medios para acceder a la información, pero existen dificultades a la hora de utilizar estos datos para resolver problemas y generar nuevos conocimientos. El uso de TIC para la atención en salud mental a poblaciones es amplio y factible de implementar en lugares distanciados geográficamente que no tienen acceso a la atención especializada en salud mental y como parte de intervenciones complejas que integran varios componentes.

La definición de Telemedicina puede parecer muy naciente y relacionado con la globalización de las comunicaciones y el desarrollo de Internet, la situación es que sobre este tema se viene trabajando desde décadas. Un concepto sencillo de Telemedicina seria como "la prestación de servicios de medicina a distancia". En el contexto actual, es de crucial importancia el conocimiento por parte de los profesionales de la salud de este nuevo método, pues de esta forma se podrá 
trabajar con la finalidad de poder desarrollarla y así descubrir nuevas estrategias. Por las proyecciones que otorga la Telemedicina en cuanto a la asistencia médica, educación a distancia e investigación científica, se convierte en imperativo profundizarla y comprender a detalle su campo de acción, su relevancia y la necesidad de desarrollar estrategias novedosas para su utilización en la atención médica (3).

Se debería trabajar por demostrar que, en tiempos futuros, la Telemedicina pueda ser útil para disminuir las deficiencias en cuanto atención de servicios de salud debido a la escasez de consultas presenciales debido a la gran demanda de pacientes, empero, deberá estar controlada y resguardada bajo criterios racionales y éticos en relación con el proceso médico- paciente.

Latinoamérica, aún se encuentra a inicios de esta nueva tecnología, se espera que el proceso de globalización conseguirá que América Latina sea participe en los avances en telemedicina. Cabe importante señalar que la implementación de la telemedicina no representara una mejora en el proceso de, pero también podría suceder que un mayor número de personas puedan acceder a mejores iniciativas diagnósticas y terapéuticas, quedando de lado la distancia geográfica y las condiciones sociales (4).

Que la aplicación de la telemedicina sea un hecho positivo o un experimento no muy favorable para Latinoamérica depende, de forma relevante, de los reflexiones y valores que predominen en las discusiones de cada sociedad y del modelo de salud que estas comunidades prefieran.

La Telepsiquiatría ha demostrado tener resultados parejos a la atención médica persona a persona, en diferentes niveles y ámbitos de atención en salud mental, con una aceptabilidad favorable por parte de los pacientes. La incorporación de la tecnología en intervenciones complejas parece ser promisoria y es una alternativa aplicada en nuestro país que ha animado a la implementación de programas entre equipos de salud general y especialistas de la salud mental a favor del usuario. Debido a esto, son relevantes los resultados que genera la aplicación de la Telepsiquiatría en nuestro país que mide y evalúa la efectividad de una colaboración entre psiquiatras para el tratamiento de las alteraciones psicopatológicas presentes en la población, con el apoyo de una plataforma informática (5).

La atención de la salud mental debe valorarse tanto como la atención de la salud física, la actualidad nos obliga a prepararnos para poder enfrentar las nuevas adversidades y promover el cuidado de la salud mental. Se destaca que la protección de la salud mental es un tema de interés para la salud pública y que requiere un manejo holístico para su correcta atención, brindando así al usuario una atención con calidad y calidez.

\section{REFERENCIAS}

1. Ventriglio A, Torales J, Castaldelli-Maia J. Telepsychiatry and social psychiatry. Int J Soc Psychiatry .2017;63 (5):387-8. https://dx.doi.org/10.1177/0020764017694661

2. Torales J, Castaldelli-Maia J, Ventriglio A. Digital Psychiatry and Digital Psychology: beyond "traditional" teletherapy. Med Clín Soc .2018;1 (3):190-1. https://dx.doi.org/10.52379/mcs.v1i3.35

3. Litewka S. Telemedicina: un desafío para américa latina. Acta Bioeth .2005;11 (2):127-32. https://dx.doi.org/10.4067/S1726$569 \times 2005000200003$

4. Jorge Fernandez M, Merida Hernandez R. Telemedicina: futuro o presente. Revista Habanera de Ciencias Médicas .2010;9 (1):127-39. URL.

5. Castro A, Larraín A, Fritsch R, Rojas G. Telepsiquiatría: una revisión sistemática cualitativa. Rev Méd Chile .2012;140 (6):789-96. https://dx.doi.org/10.4067/S0034-98872012000600015. 


\title{
Telepsychiatry: a mental health revolution in times of pandemic
}

\section{La telepsiquiatría: una revolución de la salud mental en tiempos de pandemia}

\author{
Nicolás Ayala-Servín (D)
}

\author{
1Universidad Nacional de Asunción, Facultad de Ciencias Médicas, Cátedra de Psiquiatría, San Lorenzo, Paraguay \\ ${ }^{2}$ Universidad Politécnica y Artística del Paraguay, Facultad de Medicina, Asunción, Paraguay \\ 3Universidad María Auxiliadora, Facultad de Medicina, Asunción, Paraguay.
}

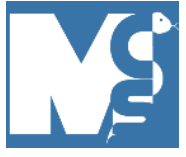

Received: $30 / 04 / 2021$

Revised: 30/04/2021

Accepted: 30/04/2021

\section{Corresponding author}

Nicolás Ayala-Servín National University of Asunción San Lorenzo - Paraguay nicoayala131292@gmail.com

\section{Conflicts of interests}

The author declares that there is no conflict of interest.

\section{Funding}

The author received no financial support for the research, authorship, and/or publication of this article.

This article is published under Creative Commons Attribution 4.0 International License.

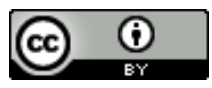

Since the last century, humanity has undergone changes in various areas of life and easy access to knowledge is facilitated through the use of new technologies capable of shortening distances.

In this context, the Information and Communication Technologies (ICTs) that we define as the computational and computer tools that process, store, synthesize and represent information in the most varied way, facilitating its registration, storage and dissemination appear. Examples are mobile devices, web pages, virtual libraries, specialized platforms, among others (1).

Mental health today faces new challenges, such as constantly reinventing and renewing methods of accessing and caring for the patient. In recent years, the Internet has become the research space where health care and health promotion processes can be developed, and scientific education should prepare health professionals to analyze and evaluate new knowledge, providing them with scientific-technological literacy that allows them to be successful.

Strategies aimed at using content management platforms for health via the Internet have been implemented in several countries, seeking to innovate, while promoting the research spirit and the right medical care with quality and warmth thanks to the advantages of ICT (2).

However, the impact of ICT on Paraguay is not yet very evident. While Internet access is growing, ICT management instruction is, in many cases, insufficient; that is, the means of accessing information are available, but there are difficulties in using this data to solve problems and generate new knowledge. The use of ICT for mental health care to populations is broad and feasible to implement in geographically distanced locations that do not have access to specialized mental health care and as part of complex interventions that integrate various components.

The definition of Telemedicine may seem very nascent and related to the globalization of communications and the development of the Internet, the situation is that this issue has been working for decades. A simple concept of Telemedicine would be "the provision of distance medicine services". In the current context, the knowledge of health professionals of this new method is of crucial importance, since this way we will be able to work in order to develop it and thus discover new strategies. Because of Telemedicine's projections of medical care, distance education and scientific research, it becomes imperative to deepen it and understand in detail its field of action, relevance and the need to develop novel strategies for use in health care (3). 
Work should be made to demonstrate that, in future times, Telemedicine can be useful in reducing deficiencies in health care due to the scarcity of face-to-face consultations due to high patient demand, however, it must be controlled and protected under rational and ethical criteria in relation to the medical-patient process.

Latin America, still at the beginning of this new technology, is expected that the globalization process will make Latin America participate in advances in telemedicine. It should be noted that the implementation of telemedicine did not represent an improvement in the process, but it could also happen that more people can access better diagnostic and therapeutic initiatives, leaving aside geographical distance and social conditions (4).

Whether the application of telemedicine is a positive fact or an experiment not very favorable for Latin America depends, in a relevant way, on the reflections and values that prevail in the discussions of each society and the health model that these communities prefer.

Telepsychiatry has been shown to have results even to human-to-person health care, at different levels and areas of mental health care, with favorable acceptability on the part of patients. The incorporation of technology into complex interventions seems to be promising and is an alternative applied in our country that has encouraged the implementation of programs between general health teams and mental health specialists in favor of the user. Because of this, the results generated by the application of Telepsychiatry in our country that measures and evaluates the effectiveness of a collaboration between psychiatrists for the treatment of psychopathological alterations present in the population, with the support of a computer platform are relevant (5).

Mental health care should be valued as much as physical health care, today it forces us to prepare to face new adversities and promote mental health care. It is emphasized that the protection of mental health is an issue of interest to public health and that it requires holistic management for its correct care, thus providing the user with quality and warmth.

\section{REFERENCES}

1. Ventriglio A, Torales J, Castaldelli-Maia J. Telepsychiatry and social psychiatry. Int J Soc Psychiatry .2017;63 (5):387-8. https://dx.doi.org/10.1177/0020764017694661

2. Torales J, Castaldelli-Maia J, Ventriglio A. Digital Psychiatry and Digital Psychology: beyond "traditional” teletherapy. Med Clín Soc .2018;1 (3):190-1. https://dx.doi.org/10.52379/mcs.v1i3.35

3. Litewka S. Telemedicina: un desafío para américa latina. Acta Bioeth .2005;11 (2):127-32. https://dx.doi.org/10.4067/S1726$\underline{569 \times 2005000200003}$

4. Jorge Fernandez M, Merida Hernandez R. Telemedicina: futuro o presente. Revista Habanera de Ciencias Médicas .2010;9 (1):127-39. $\underline{U R L}$.

5. Castro A, Larraín A, Fritsch R, Rojas G. Telepsiquiatría: una revisión sistemática cualitativa. Rev Méd Chile .2012;140 (6):789-96. https://dx.doi.org/10.4067/S0034-98872012000600015 